HORIZON 8 (2) 2019 : I. Research : J. Josl : 602-612

ФЕНОМЕНОЛОГИЧЕСКИЕ ИССЛЕДОВАНИЯ • STUDIES IN PHENOMENOLOGY • STUDIEN ZUR PHÄNOMENOLOGIE • ÉTUDES PHÉNOMÉNOLOGIQUES

https://doi.org/I0.21638/2226-5260-2019-8-2-602-612

\title{
PATOČKA'S PHILOSOPHY OF ART AND CARE FOR THE SOUL ${ }^{1}$
}

\section{JAN JOSL}

PhD in Aesthetics.

Jan Amos Komenský University, Department of Special Education. 13000 Prague, Czech Repulblic.

E-mail: josl.jan@ujak.cz

The Socratic theme of care for the soul expresses in Patočka's late thought his desire to keep the understanding of human existence as a place of turn, metanoia, of struggle between authenticity and inauthenticity. This tendency not only goes against Heidegger and his late philosophy, but is also opposed to Patočka's own earlier project of asubjective phenomenology as well. This essay argues, firstly, that the importance of subjectivity and existential dimension is still present in art and secondly, that art represents for Patočka sort of care for the soul. The argument has three stages. First, I demonstrate what Patočka means by soul or experience of soul and how we should understand the term 'care.' I argue that what Patočka understands under the concept of soul consists has freedom, krisis, and physis as its main features. The second part demonstrates that in Patockka's view, these features are present in art. The last part compares art and philosophy as two kinds of care for the soul and demonstrates the limits of art as care of the soul. My conclusion is that art represents for Patočka a limited form of care for the soul compared to philosophy. However, according to Patočka, in current situation it is the only way of care for the soul that is left.

Key words: Phenomenology, aesthetics, Jan Patočka, art, care for the soul, Socrates, Plato.

1 Shorter version of this paper was presented under the title "Art and Care of the Soul" at the conference "Heresy and Heritage: Jan Patočka on Philosophy, Politics and the Arts" in Brussels, 2.5-6.5. 2017.

(C) JAN JOSL, 2019 


\section{ФИЛОСОФИЯ ИСКУССТВА ПАТОЧКИ И ЗАБОТА О ДУШЕ 2}

\section{ЯН ЙОСЛЬ}

Доктор философии.

Университет Яна Амоса Коменского, Департамент специального образования. 13000 Прага, Чешская Республика.

E-mail: josl.jan@ujak.cz

Сократовская тема заботы о душе в мысли позднего Паточки выражает его стремление к осмыслению человеческой экзистенции как поворотного пунка, метанойи, борьбы между подлиностью и неподлиностью. Это стремление вступает в противоречие не только с поздней философией Хайдеггера, но и с собсвеным проектом Паточки по разработе несубъектной феномеологии. Данная статья покзывает, что в искусстве сохраняется значимость субъективности и экзистенции, а искусство для Пточки предсталяет собой своего род заботу о душе. Дискуссия состоит из трех пунктов. Сначала я показываю, в чем заключается душа или опыт души для Паточки и как следует понимать термин «забота». Я покзываю, что то, что Паточка имеет в виду под понятием души, заключается в свободе, krisis и physis. Из второго раздела яствует, что эти характеритики, по мнению Паточки, пристутствуют в искусстве. В третьем разделе сопоставлется искусство и философия как два типа заботы о душе; показаны ограничения искуства как заботы о душе. В заключении сделан вывод о том, что для Паточки искусство представляет собой ограниченную форму заботы о душе по сравнению с философией. Однако, с точки зрения Паточки, в настоящей ситуации это единственный тип заботы о душе, который нам остается.

Ключевые слова: Феноменология, эстетика, Ян Паточка, искусство, забота о душе, Сократ, Платон.

\section{CARE FOR THE SOUL}

Even though Patocka did not overlook the 'care for the soul' in his texts from 30s-50s it is no sooner than in 70s when Patočka makes it explicit topic of his papers. The care for the soul is the main topic in his lectures Posteuropean time and its spiritual problems (1970), Europe and Post-Europe (1970-1977) Plato and Europe (1973), and in his interpretations of Plato The oldest systems of soul science (1971) and The soul in Plato (1972) (Patočka, 1999a, b, c, d, e). Why is the author of the twentieth century returning to concept of soul? It seems that Patočka was convinced about necessity of a new concept of subjectivity. "The new concept of human subjectivity is necessary" he writes in Posteuropean time and its spiritual problems and he calls

2 Сокращенная версия этой статьи была представлена в виде доклада под названием «Искусство и забота о душе» на конференции «Ересь и наследие: Ян Паточка о философии, политике и искусстве» в Брюсселе, 2.5-6.5. 2017. 
as well for "completely new concept of phenomenon that would be different from Husserl's transcendental conception" (Patočka, 1999a, 43) ${ }^{3}$. The motivation for Patočka's new conception of subjectivity and phenomenon seems to be the fact that in his opinion the modern philosophers "Usually insufficiently thematise human dependence on the other, dependence on what is not-owned by subject" (Patočka, 1999a, 43) ${ }^{4}$. The 'own' character of subjectivity refers for Patočka to the character of home, certainty, security and it neglects unsafe and contradictory character of human existence. The modern concept of subjectivity is therefore insufficient because it does not thematise enough 'night' element of human existence, its insecurity, strangeness of the world and the experience with absolute otherness. In short it overlooks radicality of transcendence.

The concept of soul as Patočka finds it in Plato on the other hand reveals human subjectivity in a different way. Soul thematises in Plato control of ourselves, experience of uncertainty and human ignorance. It also opens ethical dimension that is missing in the modern conception of subjectivity as well:

Plato starts from experience of human existence, in its basic krisis and problemacity, which is moral by its very nature, i.e. that our being or not being is here at stake and it depends partly upon our decision upon our autokinesis. Plato does not start from cogito sum, from certainty, but from the original confusion and indecision of existence, from its movement. (Patočka, 1999c, 79) ${ }^{5}$

If Patočka returns to the concept of soul and care for the soul, it is because he wants "through new ways, new words, new methods, say the same thing" (Patocka, 1999c, 228-229) ${ }^{6}$. Patočka does not want to reestablish the concept of soul in its metaphysical meaning, rather his goal is to uncover the inspiring moments that would in the end overcome the shortages of the modern conception of subjectivity. With this intention, we must approach Patočka's concept of 'care for the soul.'

What are these inspiring moments for Patočka? The first important moment present in the concept of soul is its transcendence, conceived by Patočka as negative

3 “...zcela nový, od husserlovsky transcendentálního odlišný pojem fenoménu." (Patočka, 1999a, 43).

4 "Většinou př́liš krátce pojímají lidskou odkázanost na něco jiného, na to, co je ne-vlastní." (Patočka, 1999a, 43).

5 "Vychází Platón naopak z lidského bytí v jeho základní krisis a problematičnosti, která je bytostně mravní, tj. taková, že v ní běží o naše vlastní bytí a nebytí v částečné závislosti na nás, na našem rozhodnutí, na naší seautokinesis. Platón nevychází z cogito sum, z jistoty nýbrž z prvotního zmatku a nejistoty existence, z jejího pohybu." (Patočka, 1999c, 79).

6 "Novými zpưsoby se domáhat téhož, novými slovy, novými prostředky ř́kat totéž." 
freedom. This conception we can find in Patočka's texts Eternity and historicity (Patočka, 1996c) and in Negative Platonism (Patočka, 1996b). Following Socrates Patočka conceives freedom as human ability of transcendence, but without transcendental objective (negative moment of freedom). What Patočka does here is that he in fact reinterprets phenomenological conception of epoché in light of Socrates' philosophy. Freedom thus consists in movement of human transcendence but without Husserl's reduction to the transcendental consciousness ${ }^{7}$. Beside this Patočka mentions in the 70s that "The Greeks, the Greek philosophers in whom the Greek spirit is expressed most sharply, expressed human freedom by the term: care of the soul" (Patočka, 1999d, 160) ${ }^{8}$.

The second inspiring moment in the concept of soul we can find in Patočka's lectures on Socrates (Patočka, 1991) and Plato (Patočka, 1992) form the second half of 40s. In these lectures, Socrates represents for Patočka the first philosopher who added moral dimension to the concept of soul. In tradition since Socrates and Plato soul has not been just shadow or principle of life, but it has been responsible for human transcendence to dimensions of good and evil. In his recurrence to the concept of soul Patočka aims to emphasise that the human transcendence and moral choice between good, authentic life and bad, inauthentic life, are inseparable from each other. This moment in concept of soul that Patočka finds important I call with the reference to the tradition from which it came from as krisis.

The last feature that Patočka finds important in the concept of soul is the human relation to the final horizon, source of all manifestation, physis. This experience of physis can be found in European myths. In these myths humans are represented as those who, as well as gods, have relation to the whole. The relation to physis is at first understood as a human curse and source of our misfortune. Patočka explicitly mentions the myth about the tree of knowledge, story of Oidipus and Orestes. Philosophy is the first to see human relation to physis as an advantage because it means that "human life differs from the life of gods only in its quantitative dimension, but not in its essence: that is the solution of Greek philosophy" (Patočka, 1999d, 180).

For more complex argumentation on this question see book by Emili Tardivel (Tardivel, 2011, 33-50).

8 "Řekové, řečtí filosofové, u kterých řecký duch je vyjádřen nejostřeji, vyjádřili lidskou svobodu termínem: péče o duši." (Patočka, 1999d, 160).

9 "Lidský život je jenom svým rozměrem kvantitativním, ale nikoli svou podstatou odlišný od života božského." (Patočka, 1999d, 180). 
To sum up, these three moments: freedom, krisis (moral dimension) and physis (non-proprietary relation to the source of manifestation or being, to final horizon), are those inspiring moments in the concept of soul.

The last thing is nature of 'care.' Patočka is inspired in his conception of care by Socrates' and Plato's notion of epimeleia ${ }^{10}$. This means that 'care' consists in systematic examination of self and others. The goal of 'care' is to wake up our soul (ability of transcendence) from the original somnolence, to wake up the experience of soul and its three moments and so unravel and reflect the problemacity of human existence. The remedy of soul is traditionally special kind of logos, for Plato and Socrates it is of course philosophy. I believe that Patočka sees the healing potential not only in philosophy, but in other areas of human spiritual life as well. He often mentions politics, religion, science and art together with philosophy. In the rest of this paper I would like to show why we can consider art as a kind of 'care for the soul.'

\section{ART AND SOUL}

The first moment of soul, transcendence, is most evident in the past character of art. In his interpretation of Hegel's conception of past character of art Patočka argues that Hegel overlooked its real meaning. The past character of art does not mean as Hegel thinks that art has been surpassed by other more accurate expressions of the spirit. "The past is dimension of time as well as the time itself" writes Patočka (2004f, 341-42) ${ }^{11}$. Therefore, the past character of art does not mean the past as dimension of time as Hegel thinks, but rather the fact that in art we are related to the past in the sense of the time itself. The past as the time itself is death. In art "dies the seriousness that is typical for reality, work and human effort" (Patočka, 2004f, 343) ${ }^{12}$. In aesthetic attitude the thing and the spectator are free. They die from the practical and theoretical context. They are lifted from present to past "from world time to the time itself" (Patočka, 2004f, 345) ${ }^{13}$. However, this past and death that art is, is hidden under the aesthetic content of art, under colours, tones, stories, characters:

\footnotetext{
10 The profound analysis of concept of 'care' in Patočka's philosophy was done by Philippe Merlier (Merlier, 2009).

11 "Minulost je jednak dimenze, jednak čas vůbec." (2004f, 341-42).

12 "Hyne v ní onen charakter vážnosti, který je vlastní skutečnosti, práci, námaze, boji." (Patočka, 2004f, 343).

13 “Dílo umění se povznáší nad nitročasovost k časovosti." (Patočka, 2004f, 345).
} 
Beauty is not the awe. It is, as Rilke said, only its beginning. It is the sight of deceased looking back towards the earth, as Klee said; it is the Indian Bacchus veiling himself in sensation and image, hiding, according to Hegel, the terrifying. The negativity does not manifest itself in this its pure form, but in its positivity, in overcoming the finitude of the present moment. The beginning is principal, elementary; the principal meaning of nothingness is present in beauty, but beauty and aesthetics cannot be reduced to it. (Patočka, 2004f, 344) ${ }^{14}$

It is this past character of art that grants the presence of experience of freedom in art. Furthermore, this movement from present to past, from world time to the time in its totality, to death that is present in art are different forms of the relationship to the source of everything, relationship to being, to physis. There is no gravity of everyday struggle in art. Thus, art may seem to be a relief, a play without any seriousness. Nevertheless, art is more than a play. Compared to play in art we stand above the necessity absolutely, not only in some respect. Imagine a play of leaves in the autumn breeze. This might elicit in me free play of my cognitive faculties. Following Kant we can call this beautiful. However, art moves according to Patočka further and discovers behind simple beauty "absolute play"15 and consequently "it opens the highest human possibility that rests in freedom" (Patočka, 2004f, 343) ${ }^{16}$. In this absolute play of art we "let the things to manifest themselves in themselves. They become medium of the manifestation itself" (Patočka, 2004f, 343) $)^{17}$.

The work of art lifts itself above world time to the time itself and in this joint, where everything finite and ephemeral is put aside; the specific character of time, the world in its totality and secrets is incorporated to present, but in its reality irrelevant figure, and so the veil of awe shines in new light, in light of what is essential, in light of being. (Patočka, 2004f, 345) ${ }^{18}$

14 "Krása však není strašlivé samo, nýbrž pouze jeho počátek, jak řekl Rilke, pohled zvěčnělého zpět k zemi, jak to řekl Klee, indický Bakchus, který se halí do citu a obrazu, pod nimiž se skrývá ono strašlivé, podle výroku Hegelova. Negativita, znicotnění se neukazuje v této ryzí podobě, nýbrž ve své pozitivnosti, $\mathrm{v}$ překonání konečné př́tomnosti. Počátek je to základní, principiální; principiální význam nicoty je v kráse obsažen, ale krása a estetično se na něj neredukuje." (Patočka, 2004f, 344).

15 “absolutní hra." (Patočka, 2004f, 343).

16 “Odemyká naše nejvyšší určení, určení ke svobodě.” (Patočka, 2004f, 343).

17 "Necháváme se zjevovat $v$ jejich zjevování. Stávají se tu médiem a př́ležitostí, aby se zjevovalo samo zjevování." (Patočka, 2004f, 343).

18 "Dílo umění se povznáší nad nitročasovost k časovosti, $\mathrm{k}$ tomu skloubení, jež ze sebe vypouští ve zjevu všecko konečné a pomíjivé; konkrétní podobu časovosti, svět v jeho totalitě a tajemství, nechává vtělit se do přítomného, ale ve své realitě irelevantního útvaru, a tím tato rouška strašlivého se zaskvívá ve zvláštním světle, světle toho, co je bytostné, ve světle bytí." (Patočka, 2004f, 345). 
This ontological moment of art (physis) is for Patočka most obvious in modern art. Good example can be found in Patočka's Some Remarks on Polyperspectivity in Picasso by Walter Biemel (Patočka, 2004e). According to Patočka, the polyperspectivity in Picasso's work does not, as Biemel suggests, originate in the technological spirit of the period, but rather from the artist's efforts to go right to the elements that make painting and its manifestation possible in the first place.

Modern art thus goes back according to Patockka to the 'perception sauvage,' to perception that wants to witness how the sense is born in our senses. "It is no longer a work of art whose intention is somehow to say, to communicate, what controls its inner world-rather, the world then crystallizes into a world of meaning, which exists only in the work of art and by its grace" (Patočka, 2015, 105) $)^{19}$.

To sum up, Patočka, contrary to Hegel, does not disapprove of modern and post-Romantic art, and he discovers its genuine relationship to manifestation of the sense of being.

We see now that in art we can find all the main features of soul: freedom, krisi and physis. These moments are of course nothing else than abstractions for the sake of analysis, in real they intertwine with each other and their unity creates the movement of soul:

In short-in aesthetic attitude world' surfaces, but it is now not just a 'collection of things' but a 'harmony of meaning,' which appeared from the depths of the abyss 'aided by the participation of a finite, mortal being that is used up in this magnificent occurrence', which, as the 'birthplace' of all meaning, also raises a question about another, deeper, ultimate meaning as its unalienable point of convergence. (Patočka, $2004 c, 292)^{20}$

\section{ART AND CARE FOR THE SOUL}

Art is able to capture the sense of life and world in its totality. The examples of this function of artistic language is present in all Patočka's interpretations of literature and art. Mácha uncovered in Patočka's view the original temporality (Patočka, 2004b), Tolstoy described the phenomenology of being towards the death (Patočka, 2006b), in Tchekhov's Ivanov Patočka finds the polarity between

19 "Není to již dílo, jehož úmyslem je jaksi říci, sdělit to, co ovládá svět v něm samém—spíše svět krystalizuje posléze v svět smyslu, který existuje pouze v díle a z jeho milosti." (Patočka, 2015, 105).

20 "Krátce-v estetickém postoji se vynořuje ze své anonymity svět, nikoli již ve smyslu souboru věcí, nýbrž jako souhra smyslu, který vytanul z propastné hlubiny za pomoci a účasti konečné, smrtelné bytosti, která je vynakládána na toto v pravém významu toho slova úžasné dění, které jako rodišš všeho smyslu vyvolává a valí př̀ed sebou vždy též otázku dalšího, hlubšího, posledního smyslu jako svůj nezachytitelný úběžník." 
authenticity and inauthenticity of existence (Patočka, 2004d) and Faulkner's novel The Wild Palms represents for Patočka true nature of sacrifice and human existence in its movement of freedom (Patočka, 2004g). Art thus in its products reflects the essential features of human existence, its original ignorance towards itself, its searching, and its self-finding, in short human krisis, by colours, tones, shapes, and words of natural world in singular histories and in singular characters. Compared to philosophy artistic language (understood as one way in which we express and articulate our understanding to being) does not come up with new and general terms but uses the vocabulary of our natural language. We can sum this up in saying that by variation in fantasy art uncovers, in phenomenological sense essential structures of the world in its historical variability:

The point of art is the essential, not the real and reality. That is why the fantasy is the domain of art. The point is the essential, not the essences. That is why the singular is the domain of art, not the universals. The essential is not defined in art, it is suggested and represented, shown. This is the reason why the element of art is not clear conceptual language, but natural language in its metaphorical power, with its ability to transfer, widen or precise the meaning by its suggestive power. (Patočka, 2006b, 287-288) $)^{21}$

Art as well as philosophy represents for Patočka reflection of the world in the sense of meaningful unity. Both art and philosophy contain all important features of soul and in their activity are these features reflected. However, in Patočka's view art cannot reach in terms of care for the soul the perfection that philosophy can. The problematic points for Patočka in art are these: art represents world in "symbolic and representative forms" (Patočka, 1996a, 439), that art "is not clear conceptual language, but common language which is capable of metaphors, to transfer one meaning from one word to another, to widen the meaning or make it precise by its suggestive power" (Patočka, 2006b, 288), that art is not anxiety itself "the being in its negative appearance," but it is hidden "in feelings and pictures"(Patočka, 2004f, 344). Finally, Patočka writes: "despite of the individual key the totality of things is revealed in art only implicitly and in a disguise" (Patočka, 2006b, 291) 22.

\footnotetext{
21 "V tomto zachycení jde o podstatné, nikoli o reálné a realitu. Proto je jeho půdou fantazie. Jde o podstatné, nikoli o podstatu, proto je jeho půdou předvedení jedinečného, a nikoli obecniny. Podstatné tu není definováno, nýbrž vnuknuto a předvedeno, ukázáno. Proto elementem tu není jednoznačná pojmová řeč, nýbrž běžný jazyk se svou metaforikou, schopností přenést, rozšírit, zpřresnit význam svou sugestivní silou." (Patočka, 2006b, 287-288).

22 "A přitom je přes onen individuální klič odhalena vždy implicitně a ve způsobu zakrytosti uviversální totalita věcí." (Patočka, 2006b, 291).
} 
Philosophy on the other hand surpass art in every way. It speaks about essences and not only about essential. Where art offers only unspecified feeling, philosophy offers clear statements. While it is impossible to lead dialog with art, because the 'feelings' are arguments sans réplique ${ }^{23}$, knowledge of philosophy is born in discussion and argumentation. Compared to philosophy art seems to represent only very limited way of care of the soul. Is there any virtue left for art? I believe that there is. In Writer and his Thing Patočka writes:

Not even philosophy, which represented for a long time in the area of conceptual knowledge the holistic view on world face to face to sciences, can live up to its reputation today more than just formally. Art alone sets up claim to the holistic form of life and individuality today. (Patočka, 2006b, 292) ${ }^{24}$

It is evident that in the 60's Patočka was convinced that in our technical age even the role of philosophy as care for the soul is threatened. In interview with Josef Zumr Patočka states that his philosophical project was "to continue in the big tradition of one philosophy, not philosophy in sense of system, but as eternal discussion about the roots of prima philosophia" (Patočka, 2006a, 615). But Patočka could not find in his time a philosophy that can claim fully the title of prima philosophia. Even the philosophy of Husserl and Heidegger, in Patočka's view, did not achieve this goal. This is the reason why Patočka returns to concept of soul and looks for inspiring moments in Plato's philosophy (the original prima philosophia for Patočka). Finally, Patočka himself suggests return to prima philosophia in his project of phenomenological philosophy ${ }^{25}$. In such situation, when philosophy herself is searching its way back to the natural world, art still keeps its original relation to human existence in its problemacity, to the natural world in its whole.

${ }^{23}$ See: "The unescapable finality of our individual existence, death the inevitable and eternal fate of human is presented not in thought, but in the 'feeling:' men 'feels that he will pass forever' and in this is the 'sans réplique' of this knowledge, because emotion cannot be prove false." "Tak jest např́klad naprostá konečnost individuality, smrt jako neodvratný a věčný úděl člověka, dána nikoli úvahou, nýbrž 'citem': člověk 'cítí, že zhyne navždy, a právě v tom je character 'sans réplique' tohoto poznání, poněvadž cit se nevyvrací." (Patočka 2004a, 116).

24 "Dnes už i filosofie, která $\mathrm{v}$ oboru pojmového vědění zastupovala dlouho proti odborným vědám neroztř́štěný duchovní pohled na celek, nedovede fakticky jinak než zcela formálně udržet tento požadavek. Umění zastupuje dnes nárok životní celistvosti samo." (Patočka, 2006b, 292).

25 "Phenomenological philosophy differs from phenomenology in that it not only wants to analyse phenomena, but also wants derive results from this; it wants to derive results, as is said, that are methaphysical"/ "Fenomenologická filosofie se liší od fenomenologie tím, že nechce jenom rozebírat fenomény jako takové, nýbrž chce $\mathrm{z}$ toho vyvodit take důsledky, chce z toho vyvodit důsledky, jak se ř́ḱá, metafyzické." (Patočka, 1999d, 177). 
Art is not perfect of course. All these things are in art hidden or present only implicitly. Art is not about temporality of human existence, nor about time and space as basic forms of our experience. Art is story of two lovers, figure of Apollon, melody of song. Nevertheless, in the way art uses the terms of natural world the logos of art highlights these basic structures of our common world, that make the understanding between artist and spectator possible. This is the source of our persistent feeling that in art there is more than we see at the first sight. There is always more in art, there is our world in a nutshell. Patočka saw this in Mácha or Dostoyevsky. Thus art is not perfectly clear reflection of natural world and human existence, but it is the first step on our path for beautiful soul.

\section{REFERENCES}

Merlier, P. (2009). Patočka: Le soin de l'âme et l'Europe. Paris: L'Harmattan.

Patočka, J. (1991). Sokratés. Prague: SPN.

Patočka, J. (1992). Platón. Prague: SPN.

Patočka, J. (1996a). Filosofie výchovy [Philosophy of Education]. In J. Patočka, Péče o duši [Care for the Soul, Vol. I]. Prague: Oikoymenh. (in Czech).

Patočka, J. (1996b). Negativní Platonismus [Negative Platonism]. In J. Patočka, Péče o duši [Care for the Soul, Vol. I]. Prague: Oikoymenh. (in Czech).

Patočka, J. (1996c). Věčnost a dějinnost [Eternity and Historicity]. In J. Patočka, Péče o duši [Care for the Soul, Vol. I]. Prague: Oikoymenh. (in Czech).

Patočka, J. (1999a). Doba poevropská a její duchovní problémy [Posteuropean Time and its Spiritual Problems]. In J. Patočka, Péče o duši [Care for the Soul, Vol. I]. Prague: Oikoymenh. (in Czech).

Patočka, J. (1999b). Evropa a doba poevropská [Europe and Post-Europe]. In J. Patočka, Péče o duši [Care for the Soul, Vol. I]. Prague: Oikoymenh. (in Czech).

Patočka, J. (1999c). O duši u Platóna [The Soul in Plato]. In J. Patočka, Péče o duši [Care for the Soul, Vol. II]. Prague: Oikoymenh. (in Czech).

Patočka, J. (1999d). Platón a Evropa [Plato and Europe]. In J. Patočka, Péče o duši [Care for the Soul, Vol. II]. Prague: Oikoymenh. (in Czech).

Patočka, J. (1999e). Počátky systematické psychologie [The Oldest Systems of Soul Science]. In J. Patočka, Péče o duši [Care for the Soul, Vol. II]. Prague: Oikoymenh. (in Czech).

Patočka, J. (2004a). Symbol země u K. H. Máchy [Symbol of Earth in K. H. Mácha]. In J. Patočka, Umění a čas [Art and Time, Vol I]. Prague: Oikoymenh. (in Czech).

Patočka, J. (2004b). Čas, věčnost a časovost v Máchově díle [Time, Eternity and Temporality in Macha's Work]. In J. Patočka, Umění a čas [Art and Time, Vol I]. Prague: Oikoymenh. (in Czech).

Patočka, J. (2004c). Hegelův filosofický a estetický vývoj [Hegel’s Philosophical and Aesthetic Development]. In J. Patočka, Uméní a čas [Art and Time, Vol I]. Prague: Oikoymenh. (in Czech).

Patočka, J. (2004d). Ivanov. In J. Patočka, Umění a čas [Art and Time, Vol I]. Prague: Oikoymenh. (in Czech). 
Patočka, J. (2004e). Poznámky k polyperspektivě u Picassa od W. Biemela [Some Remarks on Polyperspectivity in Picasso by Walter Biemel]. In J. Patočka,Umění a čas [Art and Time, Vol II]. Prague: Oikoymenh. (in Czech).

Patočka, J. (2004f). Učení o minulém rázu umění [Hegel's Thesis on the Past Character of Time]. In J. Patočka, Umění a čas [Art and Time, Vol I]. Prague: Oikoymenh. (in Czech).

Patočka, J. (2004g). Zpěv výsostnosti [Song of Sovereignity] In J. Patočka, Umění a čas [Art and Time, Vol I]. Prague: Oikoymenh. (in Czech).

Patočka, J. (2006a). K filosofovým šedesátinám [To Philosophers Sixtieth Anniversary]. In J. Patočka, Češi [Czechs, Vol. I]. Prague: Oikoymenh. (in Czech).

Patočka, J. (2006b). Spisovatel a jeho věc [Writer and His Thing]. In J. Patočka, Češi [Czechs, Vol. I]. Prague: Oikoymenh. (in Czech).

Patočka, J. (2015). Art and Time. Estetika: The Central European Journal of Aesthetics, 52(1), 99-113.

Tardivel, E. (2011). La liberté au principe: Essai sur la philosophie de Patočka. Paris: Vrin. 